\title{
Response of long-, medium- and short-term processes of the carbon budget to overgrazing-induced crusts in the Tibetan Plateau
}

\author{
Sebastian Unteregelsbacher • Silke Hafner • \\ Georg Guggenberger • Georg Miehe • \\ Xingliang Xu $\cdot$ Jianquan Liu $\cdot$ Yakov Kuzyakov
}

Received: 31 January 2011 / Accepted: 28 July 2011/Published online: 31 August 2011

(C) The Author(s) 2011. This article is published with open access at Springerlink.com

\begin{abstract}
The Kobresia pastures of the Tibetan Plateau represent the world's largest alpine grassland ecosystem. These pastures remained stable during the last millennia of nomadic animal husbandry. However, strongly increased herds' density has promoted overgrazing, with unclear consequences for vegetation and soils, particularly for cycles of carbon (C), nutrients and water. Vegetation-free patches of dead
\end{abstract}

S. Unteregelsbacher · S. Hafner · Y. Kuzyakov Department of Agroecosystem Research, BayCEER, University of Bayreuth, Bayreuth, Germany

\section{G. Guggenberger}

Institute of Soil Science, Leibniz Universität Hannover, Hannover, Germany

\section{G. Miehe}

Faculty of Geography, University of Marburg, Marburg, Germany

\section{$\mathrm{X} . \mathrm{Xu} \cdot \mathrm{Y}$. Kuzyakov}

Key Laboratory of Ecosystem Network Observation and Modelling, Institute of Geographic Sciences and Natural Resources Research, Chinese Academy of Sciences, 11A, Datun Road, Chaoyang District, Beijing 100101, China

\section{J. Liu}

Northwest Institute Plateau Biology Xining,

CAS, Xining, Qinghai, China

\section{Y. Kuzyakov ( $\square)$}

Department of Soil Science of Temperate Ecosystems, University of Göttingen, 37077 Göttingen, Germany

e-mail: kuzyakov@gwdg.de root-mat covered by blue-green algae and crustose lichens (crusts) are common in overgrazed Kobresia pastures, but their effect on $\mathrm{C}$ turnover processes is completely unknown. We tested the hypothesis that the crusts strongly affect the $\mathrm{C}$ cycle by examining: (i) the long-term $\mathrm{C}$ stock measured as soil organic matter content; (ii) medium-term $\mathrm{C}$ stock as dead roots; (iii) recent $\mathrm{C}$ fluxes analyzed as living roots and $\mathrm{CO}_{2}$ efflux; and (iv) fast decomposition of root exudates. Up to 7.5 times less aboveground and 1.9 times less belowground living biomass were found in crust patches, reflecting a much smaller $\mathrm{C}$ input to soil as compared with the non-crust Kobresia patches. A lower $\mathrm{C}$ input initially changed the long-term $\mathrm{C}$ stock under crusts in the upper root-mat horizon. Linear regression between living roots and $\mathrm{CO}_{2}$ efflux showed that roots contributed $23 \%$ to total $\mathrm{CO}_{2}$ under non-crust areas (mean July-August $5.4 \mathrm{~g} \mathrm{C} \mathrm{m}^{-2} \mathrm{day}^{-1}$ ) and $18 \%$ under crusts $\left(5.1 \mathrm{~g} \mathrm{C} \mathrm{m}^{-2} \mathrm{day}^{-1}\right)$. To identify differences in the fast turnover processes in soil, we added ${ }^{13} \mathrm{C}$ labeled glucose, glycine and acetic acid, representing the three main groups of root exudates. The decomposition rates of glucose $\left(0.7 \mathrm{day}^{-1}\right)$, glycine $\left(1.5 \mathrm{day}^{-1}\right)$ and acetic acid $\left(1.2 \mathrm{day}^{-1}\right)$ did not differ under crusts and non-crusts. More ${ }^{13} \mathrm{C}$, however, remained in soil under crusts, reflecting less complete decomposition of exudates and less root uptake. This shows that the crust patches decrease the rates of medium-term $\mathrm{C}$ turnover in response to the much lower $\mathrm{C}$ input. Very high ${ }^{13} \mathrm{C}$ amounts recovered in plants from non-crust areas as well as the two times 
lower uptake by roots under crusts indicate that very dense roots are efficient competitors with microorganisms for soluble organics. In conclusion, the altered $\mathrm{C}$ cycle in the overgrazing-induced crustose lichens and blue-green algae crusts is connected with strongly decreased $\mathrm{C}$ input and reduced medium-term C turnover.

Keywords Overgrazing - Land-use changes . Kobresia pasture - Root exudates $\cdot{ }^{13} \mathrm{C}$ pulse labeling $\cdot \mathrm{CO}_{2}$ efflux from soil $\cdot$ Soil organic carbon . Soil respiration

\section{Introduction}

The Tibetan Plateau (TP), with an average altitude of more than $4000 \mathrm{~m}$ above sea level and an area of $2.5 \times 10^{6} \mathrm{~km}^{2}$, is the largest and highest plateau on Earth (Lu et al. 2004). Over $60 \%$ of the plateau is covered by grasslands (Zhang et al. 2007), representing a very important part of the global grassland ecosystems. Grassland soils in the TP store a huge amount of organic carbon (C) (33.52 $\mathrm{Pg} \mathrm{C}$ in the upper $0.75 \mathrm{~m}$ of topsoil), which represents approximately $2.5 \%$ of the global soil C stock (Ni 2002; Wang et al. 2002). Therefore, $C$ dynamics in grasslands in the $\mathrm{TP}-\mathrm{C}$ stocks, $\mathrm{C}$ turnover and $\mathrm{CO}_{2}$ fluxes-play a very important role in regional and global C cycles (Zhang et al. 2007; Zhao et al. 2005). The response of these $C$ stocks and processes to recent land use changes remains unknown.

The Kobresia pastoral ecosystem of the eastern Tibetan highland is crucial in determining the $\mathrm{C}$ and water balance of the TP and is highly susceptible to climate and land-use changes. The Kobresia pastures form a dense vegetation cover of Cyperaceae turf named "Kobresia turf" ("Rhizomull", Afe horizon, Kaiser et al. 2007), with a very dense root system in the top $15 \mathrm{~cm}$ of soil. This makes the Kobresia pastures very durable and resistant to trampling by yaks and sheep (Cao and Long 2009). The Kobresia pastoral ecosystem is grazing-dependent, induced and maintained by herders and their livestock (Miehe et al. 2008a). Intact Kobresia pastures probably have a neutral net ecosystem $\mathrm{CO}_{2}$ exchange (Shi et al. 2006). They may even represent a moderate $C$ sink
(Ni 2002; Wu et al. 2010; Zhao et al. 2006), mainly in the aboveground plant parts that are removed by grazing. Although this ecosystem has been quite stable during the last centuries or millennia of nomadic animal husbandry (Miehe et al. 2008a), minor changes in internal or external drivers may significantly alter the soil organic $\mathrm{C}$ pool. This, in turn, influences the atmospheric $\mathrm{CO}_{2}$ concentration and the global climate (Cui and Graf 2009).

Strongly increased density of herding animals and sedentarisation programs enforced in the TP since the early 1980s (Gad 2005) induced strong land-use and vegetation changes, with drastic consequences for $\mathrm{C}$, $\mathrm{N}$ and water cycles. The concentration of grazing around the villages leads to overgrazing and land degradation (Zhao and Zhou 1999). In the worst stages of degradation the Kobresia turf cover is completely removed; the exposed silt (Bkc or even $\mathrm{Ck}$ horizons) is prone to deflation and water erosion (Wang and Cheng 2000; Miehe et al. 2011). Overgrazing also changes the vegetation (Ning and Richard 1999) and its pattern. The present structure of many overgrazed Kobresia pastures is characterized by open turf/root-mat covered only by blue-green algae and crustose lichens (termed 'crust' in this study); this closely adjoins pastures dominated by graminoids and Kobresia species. On the adjacent plots we found that there are no crusts in grazing exclosure older than 8 years (Hafner et al. 2011 under review) and in those pastures without heavy grazing. This indicates that strong overgrazing increases the percentage of the crust area and thus decreases ecosystem productivity and grassland quality. Many dead and partly decomposed Kobresia roots (rootmat, frequently termed "root-felt") are present under such crusts. Based on the obvious differences between crust and Kobresia grassland (non-crust) in living biomass, both above- and belowground, we hypothesized that root exudates have a different fate (microbial decomposition and remaining in the soil) and thus, reflect short- to medium-term $\mathrm{C}$ turnover processes. Correspondingly, we hypothesized that decreased $\mathrm{C}$ input under crusts reduces the mediumand long-term organic $\mathrm{C}$ stock, turning this ecosystem part into a $\mathrm{C}$ source. This can be traced by comparing $\mathrm{CO}_{2}$ efflux with $\mathrm{C}$ input. Recognizing and evaluating possible changes in the $\mathrm{C}$ cycle of this ecosystem requires determining the $\mathrm{C}$ fluxes between $\mathrm{C}$ pools along with the related storage and internal turnover. 
To investigate the effects of overgrazing on processes of $\mathrm{C}$ turnover, we investigated $\mathrm{C}$ dynamics in soil under the two contrasting patches of vegetation: (i) blue-green algae and crustose-lichens (crust) and (ii) grass composed predominantly of Kobresia and Stipa species (non-crust), in a montane-alpine grassland (Kobresia-Stipa pasture) on the TP. Based on the predicted different response of $\mathrm{C}$ stocks and turnover processes depending on the characteristic residence times and rates, we evaluated (i) the longterm $\mathrm{C}$ stock (decades) by the soil organic matter content; (ii) the medium-term $\mathrm{C}$ stock (years) by the amount of dead roots; (iii) recent $\mathrm{C}$ stock and $\mathrm{C}$ input (months) by the amount of living roots, whereby the $\mathrm{C}$ fluxes were measured as $\mathrm{CO}_{2}$ efflux from soil, as well as remaining ${ }^{13} \mathrm{C}$ from exudates; and (iv) fast $\mathrm{C}$ turnover based on ${ }^{13} \mathrm{C}$ labeled substances representing root exudates.

\section{Materials and methods}

Field sites and soil

The experimental site is located in Qinghai province in the northeastern Tibetan Plateau, approximately $200 \mathrm{~km}$ southwest of Xining, about $15 \mathrm{~km}$ south of Xinghai city (longitude $35^{\circ} 32^{\prime} \mathrm{N}$, latitude $99^{\circ} 51^{\prime} \mathrm{E}$ ). The montane-alpine grassland has developed on a loess-covered $(\sim 1.2 \mathrm{~m})$ terrace of the Huang $\mathrm{He}$ River (3417 m a.s.1.). The grassland is classified as Kobresia humilis/pygmaea-Stipa pasture and used as a winter pasture for yaks and sheep for 6-7 months of the year (Miehe et al. 2008b). About 20\% of the pasture at the experiment site is completely covered with blue-green algae and crustose-lichens (crust) (Fig. 1).

Due to the East Asian monsoon, almost all of the precipitation falls in the summer months from May to September, most frequently in the form of torrential rain during afternoon thunderstorms. The annual precipitation (Xinghai climate station) averaged $353 \mathrm{~mm}$, ranging from 214 to $483 \mathrm{~mm}$ during 40 years from 1961 to 2001 . The rain gauge nearest to the study site recorded $448 \mathrm{~mm} \mathrm{a}^{-1}$ (2002-2007). Winter snowfall is irregular and rare (Miehe et al. 2008b). In Xinghai, mean monthly temperatures lie above $5^{\circ} \mathrm{C}$ between May and September, and above $10^{\circ} \mathrm{C}$ from June to August. During the wintertime, the north-east of the TP is subject to the Siberian high pressure system. Mean monthly temperatures for December and January in Xinghai lie below $-10^{\circ} \mathrm{C}$. The mean monthly temperature for the coldest month is $-20.8^{\circ} \mathrm{C}$, and the absolute low was $-33.5^{\circ} \mathrm{C}$ (Miehe et al. 2008b).

The soil is classified as a Haplic Kastanozem (WRB 2006) with three characteristic horizons. The upper horizon consists of a high quantity of fine

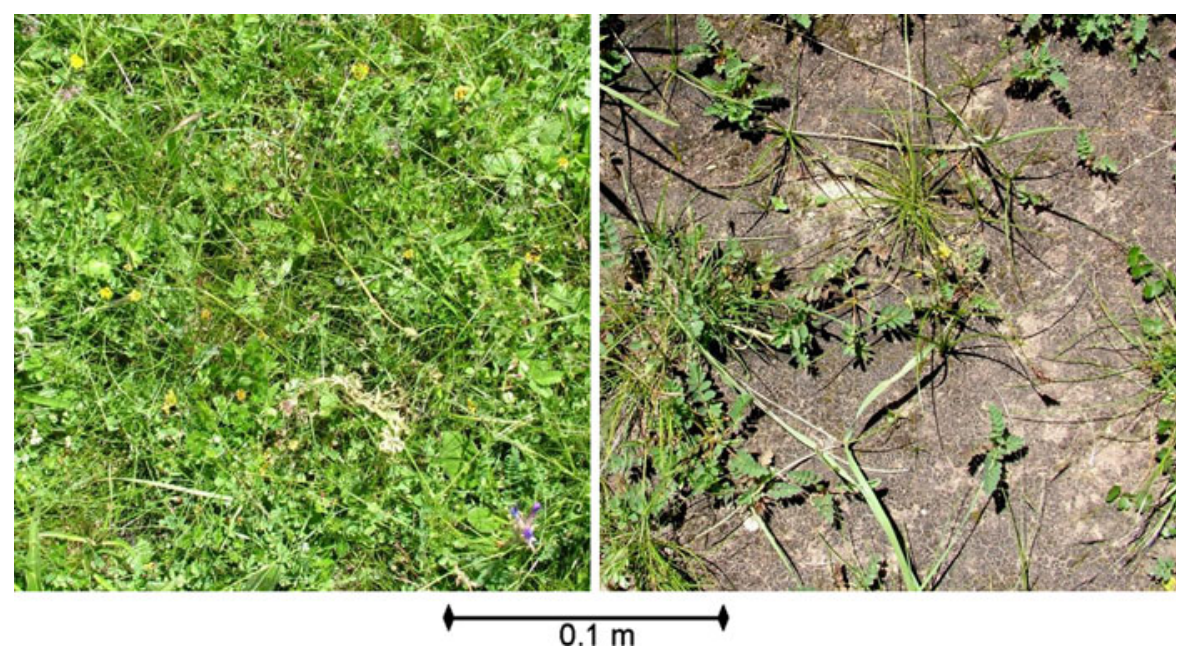

Fig. 1 Two contrasting patches of vegetation at the study site (Qinghai province) common for the Tibetan Plateau: a Grassland with $100 \%$ vegetation cover with predominant Kobresia and Stipa species (left), and b Blue-green algae and crustose lichens above the dead Kobresia pigmea turf (right). The cover of crust patches is less than $30 \%$ with the predominance of the same species 
sedge-roots (Kobresia) and generates a felty turf known as "Kobresia turf" (Kaiser et al. 2007).

\section{Labeling procedure}

In July 2009 we conducted a field ${ }^{13} \mathrm{C}$ labeling experiment with representatives of typical root exudates (Kraffczyk et al. 1984; Fischer et al. 2010a, b): glucose (representative for sugars), glycine (for amino acids) and acetic acid (for carboxylic acids) were added in situ to the two contrasting patches of vegetation (Fig. 1):

i) Grassland (vegetation cover approximately $100 \%$ ) with predominant Kobresia and Stipa species (non-crust).

ii) The same species cover $<50 \%$ of the soil. More than $50 \%$ of the surface is covered by root felt with blue-green algae and crustose-lichens (crust).

Twelve plots $(0.3 \times 0.3 \mathrm{~m})$ were set up for three substances in either of patches. There were four replicates for each substance. In total, there were 24 plots for the labeling experiment. All the three substances were labeled by 99 atom $\%{ }^{13} \mathrm{C}$ (Campro Scientific $\mathrm{GmbH}$ ). A total amount of $12.6 \mathrm{mg} \mathrm{C}$ was applied to each plot, equaling to $334 \mathrm{mg}$ glucose, $415 \mathrm{mg}$ glycine and $334 \mathrm{mg}$ acetic acid per square meter, respectively. The labeled substances (glucose, glycine, acetic acid) were dissolved in $150 \mathrm{ml}$ water, and then uniformly sprayed on the respective plots using a small watering can. After the substances were added, additional distilled water $(300 \mathrm{ml})$ was slowly sprayed to each plot to ensure that no labeled substances remained on the leaves of vegetation.

$\mathrm{CO}_{2}$ efflux from soil

$\mathrm{CO}_{2}$ efflux from soil was analyzed by two approaches. The first approach was focused on sampling $\mathrm{CO}_{2}$ for further ${ }^{13} \mathrm{C}$ analyses. After the labeling, at each plot a small part of vegetated area (if present) was cut close to the soil surfaces and a round aluminum chamber (diameter 5.2 , height $4.0 \mathrm{~cm}$ ) was pushed $5 \mathrm{~mm}$ into the soil of the plots and sealed with wet silt to avoid $\mathrm{CO}_{2}$ loss. The $\mathrm{NaOH}$ solution was placed inside the chamber to trap $\mathrm{CO}_{2}$ for estimation of ${ }^{13} \mathrm{C}$ loss via soil respiration. The $\mathrm{NaOH}$ solution was exchanged on days $1,4,9,18$ and 29 after the labeling. Increasing amount of $\mathrm{NaOH}$ solution was used for the intervals so that the $\mathrm{NaOH}$ solution was enough to trap all $\mathrm{CO}_{2}$ released from soil. The data of $\mathrm{CO}_{2}$ efflux measured by this approach was related to the amount of living roots separated from soil sampled at the same time and locations, where the $\mathrm{CO}_{2}$ efflux was measured. This allows to evaluate the contributions of root respiration and soil organic matter derived $\mathrm{CO}_{2}$ to the total $\mathrm{CO}_{2}$ by the linear regression approach (Kucera and Kirkham 1971).

The second approach was focused on evaluation of diurnal dynamics of $\mathrm{CO}_{2}$ fluxes. $\mathrm{CO}_{2}$ efflux from soil was determined by closed round chambers (diameter $12 \mathrm{~cm}$ and height $10 \mathrm{~cm}$ ). This was done in adjacent plots including non-crust and crust patches. The increase of $\mathrm{CO}_{2}$ concentration (ppm) inside the chamber was measured by a $\mathrm{CO}_{2}$-meter (VAISALA Hand-held $\mathrm{CO}_{2}$ Meter GM70, Helsinki, Finland) every $20 \mathrm{~s}$ during $300 \mathrm{~s}$. The diurnal dynamics of $\mathrm{CO}_{2}$ fluxes from soil with and without crusts were measured by the same closed chamber approach.

When the $\mathrm{NaOH}$ solution was exchanged, shoots, roots and soil were collected from each plot. Plants were cut at the base and soil was divided in the layers $0-5 \mathrm{~cm}, 5-15 \mathrm{~cm}$ and $15-30 \mathrm{~cm}$ using a $2.1 \mathrm{~cm}$ diameter soil corer. The soil was sieved $(2 \mathrm{~mm})$ and roots were separated from bulk soil by handpicking. Roots were divided into living and dead according to color. All soil and plant samples were dried at $60^{\circ} \mathrm{C}$ and prepared for $\delta^{13} \mathrm{C}$ analyses.

\section{Sample preparation and analyses}

Dried samples of soils, shoots and roots were weighed and then ground by a ball mill prior to $\delta^{13} \mathrm{C}$ analysis. Carbonates in soil were completely destroyed during four days in an exsiccator with an atmosphere of concentrated $\mathrm{HCl}(37 \% \mathrm{HCl})$. To remove the remaining $\mathrm{HCl}$ before $\delta^{13} \mathrm{C}$ analysis, distilled water was added and soil samples were frozen-dried until a $\mathrm{pH}$ of 7 . All data on $\mathrm{C}$ stocks and fluxes were reported for organic $\mathrm{C}$ only (except $\mathrm{CO}_{2}$ efflux from soil). We accepted that the possible changes of $\mathrm{CaCO}_{3}$ in Ahk, Bkc and the parent loess (Ck) are too small to be measured because recrystallization periods of pedogenic carbonates take centuries to millennia (Kuzyakov et al. 2006; Gocke et al. 2011). 
The total $\mathrm{CO}_{2}$ trapped in the $\mathrm{NaOH}$ was analyzed in an aliquot by titration with $0.1 \mathrm{M} \mathrm{HCl}$ against phenolphthalein after adding strontium chloride $\left(\mathrm{SrCl}_{2}\right)$. The $\mathrm{CO}_{2}$ trapped in $\mathrm{NaOH}$ was precipitated with $0.5 \mathrm{M} \mathrm{SrCl}_{2}$ aqueous solution and the $\mathrm{SrCO}_{3}$ precipitants were washed with deionized water to remove $\mathrm{NaOH}$ and to reach a $\mathrm{pH}$ of 7 . After washing, the remaining water was removed from the vials and the $\mathrm{SrCO}_{3}$ was dried for $\delta^{13} \mathrm{C}$ analyzes.

The relative ${ }^{13} \mathrm{C}$ abundance, and total $\mathrm{C}$ and $\mathrm{N}$ contents in the samples of plants, soils and $\mathrm{SrCO}_{3}$ were analyzed using a $\mathrm{C}-\mathrm{N}$ analyzer (CE Instruments, Milano, Italy) coupled via a ConFlo III (Finnigan MAT, Bremen, Germany) to an isotope ratio mass-spectrometer Delta Plus (IRMS-a NA 1108, Finnigan MAT).

\section{Calculations and statistics}

$\mathrm{CO}_{2}$ efflux rates were calculated using a linear increase of $\mathrm{CO}_{2}$ concentration measured every $20 \mathrm{~s}$ during $300 \mathrm{~s}$ by a $\mathrm{CO}_{2}$-meter. Partitioning of total $\mathrm{CO}_{2}$ efflux for root-derived $\mathrm{CO}_{2}$ and the sum of SOM-derived $\mathrm{CO}_{2}$ and microbial decomposition of dead plant residues was estimated by a linear regression approach (Kucera and Kirkham 1971; Kuzyakov 2006). The linear relationship between root biomass and total $\mathrm{CO}_{2}$ efflux rate was extrapolated to yield a Y-intercept value. This indicates the minimum microbial respiration in the absence of living roots, corresponding to the SOM-derived $\mathrm{CO}_{2}$ and microbial decomposition of dead plant residues.

To calculate the decomposition rate of ${ }^{13} \mathrm{C}$ labeled representatives of root exudates and their metabolites, a single first-order kinetics was fitted to the experimental data for $\mathrm{CO}_{2}$.

${ }^{13} \mathrm{C}_{\mathrm{tot}}=\mathrm{C}_{0} \cdot \exp \left(-k_{\mathrm{CO}_{2}} \cdot t\right)+$ Const

${ }^{13} \mathrm{C}_{\mathrm{tot}}=\mathrm{C}_{0} \cdot\left(1-\exp \left(-k_{\mathrm{CO}_{2}} \cdot t\right)\right)+$ Const

${ }^{13} \mathrm{C}_{\text {tot }}$ is the amount of ${ }^{13} \mathrm{C}$ label in a certain pool at a sampling time $(t), \mathrm{C}_{0}$ is the maximum flux out of the pool at the beginning, $k_{\mathrm{CO}_{2}}$ describes the decomposition rate constant, and the parameter Const describes the remaining ${ }^{13} \mathrm{C}$ label for which biodegradation cannot be described using the exponential decay approach during the 29 days. Equation 2 was used for all cumulative data.
A single first-order decay equation was also fitted to the ${ }^{13} \mathrm{C}$ recovered from the soil to describe the remaining exudates and their metabolites (Eq. 3).

${ }^{13} \mathrm{C}_{\mathrm{tot}}=\mathrm{C}_{0} \cdot \exp \left(-k_{\text {soil }} \cdot t\right)+$ Const

$k_{\text {soil }}$ is the decline rate of the initial exudates and their metabolites remaining in soil. The half-lives $\left(t_{1 / 2}\right)$ of

${ }^{13} \mathrm{C}$ exudates and their metabolites were calculated as follows:

$\mathrm{t}_{1 / 2}=\ln (2) / \mathrm{k}$

Significant effects of crust vs. non-crust on soil organic $\mathrm{C}$, aboveground biomass, living and dead roots was tested by ANOVA at $p<0.05$ (Statistica ver. 7.0). Nonlinear regressions were used to fit the parameters of Eqs. 1-3. Means and standard errors are presented in Tables and Figures.

\section{Results}

Above- and belowground carbon stock

The presence of crust significantly affected the above- and belowground $\mathrm{C}$ pools (Table 1), i.e., strongly decreased aboveground biomass $(p<0.001)$ and living roots $(0-5 \mathrm{~cm})(p<0.001)$, and increased the amount of dead roots $(0-5 \mathrm{~cm})(p<0.01)$. In the non-crust area the shoot biomass was about 7.5 times higher than in the crusted area, while the $\mathrm{C}$ stored in the living roots $(0-30 \mathrm{~cm})$ was about two times higher than in the crusted area. Although the noncrust soil contained more organic $\mathrm{C}$ in the upper $5 \mathrm{~cm}$ $(p<0.05)$, the $\mathrm{C}$ stock in the upper $30 \mathrm{~cm}$ was not significantly different between crust and non-crust. When living and dead roots were also considered, more $\mathrm{C}$ was stored belowground in the non-crust patches. This data on changes of $\mathrm{C}$ stocks are highly representative as they are based on 120 replications for each treatment. The decrease of the total belowground $\mathrm{C}$ stock under crusts was mainly due to living roots, but also due to decreasing organic $\mathrm{C}$ content in the upper $5 \mathrm{~cm}$.

$\mathrm{CO}_{2}$ efflux from the soil

Although the above- and belowground living biomass (Table 1) was significantly smaller in crust patches, 
Table 1 Organic carbon stocks above and below ground in the plant-soil system and $\mathrm{CO}_{2}$ efflux from soil

\begin{tabular}{|c|c|c|c|}
\hline \multirow[t]{2}{*}{ Pool } & \multicolumn{2}{|c|}{ Organic carbon stock $\left(\mathrm{g} \mathrm{C} \mathrm{m}^{-2}\right)$} & \multirow{2}{*}{$\begin{array}{l}\text { Ratio } \\
\text { Non-crust/crust }\end{array}$} \\
\hline & Non-crust & Crust & \\
\hline Plant biomass total & $517 \pm 91.4^{\mathrm{a}}$ & $201 \pm 47.6^{\mathrm{b}}$ & 2.6 \\
\hline Above ground (shoots) & $176 \pm 14.1^{\mathrm{a}}$ & $23.6 \pm 5.9^{\mathrm{b}}$ & 7.5 \\
\hline Below ground (living roots ${ }^{\mathrm{A}}$ ) & $341 \pm 77.3^{\mathrm{a}}$ & $177 \pm 41.7^{\mathrm{b}}$ & 1.9 \\
\hline $0-5 \mathrm{~cm}$ & $125 \pm 17.3^{\mathrm{a}}$ & $49.2 \pm 11.1^{\mathrm{b}}$ & 2.5 \\
\hline $5-15 \mathrm{~cm}$ & $105 \pm 12.4^{\mathrm{a}}$ & $70.9 \pm 12.2^{\mathrm{b}}$ & 1.5 \\
\hline $15-30 \mathrm{~cm}$ & $111 \pm 47.6^{\mathrm{a}}$ & $57.0 \pm 18.4^{\mathrm{b}}$ & 1.9 \\
\hline Dead roots $(0-5 \mathrm{~cm})$ & $46.6 \pm 5.9^{\mathrm{a}}$ & $74.9 \pm 7.1^{\mathrm{b}}$ & 0.6 \\
\hline Ratio: shoots/living roots $(0-30 \mathrm{~cm})$ & $0.52^{\mathrm{a}}$ & $0.13^{\mathrm{b}}$ & 4.0 \\
\hline Ratio: living roots/dead roots $(0-5 \mathrm{~cm})$ & $2.68^{\mathrm{a}}$ & $0.66^{\mathrm{b}}$ & 4.1 \\
\hline Soil organic $\mathrm{C}$ total & $8712 \pm 460$ & $8715 \pm 698$ & 1.0 \\
\hline $0-5 \mathrm{~cm}$ & $2775 \pm 93.6^{\mathrm{a}}$ & $2375 \pm 96.8^{\mathrm{b}}$ & 1.2 \\
\hline $5-15 \mathrm{~cm}$ & $3405 \pm 172$ & $3444 \pm 215$ & 1.0 \\
\hline $15-30 \mathrm{~cm}$ & $2532 \pm 195$ & $2896 \pm 386$ & 0.9 \\
\hline $\mathrm{CO}_{2}$ efflux from soil ${ }^{\mathrm{B}}\left(\mathrm{g} \mathrm{C} \mathrm{m}^{-2}\right.$ day $\left.^{-1}\right)$ & $5.44 \pm 0.21$ & $5.09 \pm 0.27$ & 1.1 \\
\hline
\end{tabular}

Organic carbon stocks represent means \pm SE $(n=120)$. Small letters show significant differences between Non-crust and Crust The significance of all differences except for soil $\mathrm{C}$ pools is at least with $p<0.01$

A The amount of living roots may be underestimated because of very high amount of dead roots and very dense Kobresia root-mats hindering complete extraction of living roots

B $\mathrm{CO}_{2}$ efflux from soil is an average for July-August 2009 calculated based on cumulative $\mathrm{CO}_{2}$ trapping in $\mathrm{NaOH}$

there were no significant differences between the $\mathrm{CO}_{2}$ efflux from soil under crust and non-crust $(p>0.05$; Table 1). The soil $\mathrm{CO}_{2}$ efflux rate averaged $21.2 \pm$ $1.1 \mathrm{mg} \mathrm{CO} \mathrm{CO}_{2}-\mathrm{C} \mathrm{m}^{-2} \mathrm{~h}^{-1}$ in crust patched and $22.7 \mathrm{mg}$ $\mathrm{CO}_{2}-\mathrm{C} \mathrm{m}^{-2} \mathrm{~h}^{-1}$ in non-crust patches during 29 days (Table 1).

The $\mathrm{CO}_{2}$ effluxes from crust and non-crust patches showed clear diurnal dynamics (Fig. 2). The minimum occurred at night and amounted to $6.88 \pm 0.92$ and $8.54 \pm 0.67 \mathrm{mg} \mathrm{CO}_{2}-\mathrm{C} \mathrm{m}^{-2} \mathrm{~h}^{-1}$ in crust and noncrust patches, respectively. Sunlight after 9:00 am strongly increased the surface temperature, photosynthetic activity and soil respiration, increasing the soil $\mathrm{CO}_{2}$ efflux rate accordingly. The maximum efflux occurred between 12:00 and 1:00 pm, with rates of $21.4 \pm 2.3$ and $27.6 \pm 0.9 \mathrm{mg} \mathrm{CO} \mathrm{CO}_{2}-\mathrm{C} \mathrm{m}^{-2} \mathrm{~h}^{-1}$ for crust and non-crust patches, respectively (Fig. 2).

A significant correlation was observed between living root biomass and total $\mathrm{CO}_{2}$ efflux from soil $(p<0.001)$. This allowed us separating the $\mathrm{CO}_{2}$ derived from living roots (root and rhizomicrobial respiration) from the sum of microbial decomposition of SOM and dead plant remains. The $\mathrm{Y}$ intercept of $17.5 \mathrm{mg} \mathrm{CO} 2^{-}$ $\mathrm{C} \mathrm{m}^{-2} \mathrm{~h}^{-1}$ (Fig. 3) indicates the microbial respiration

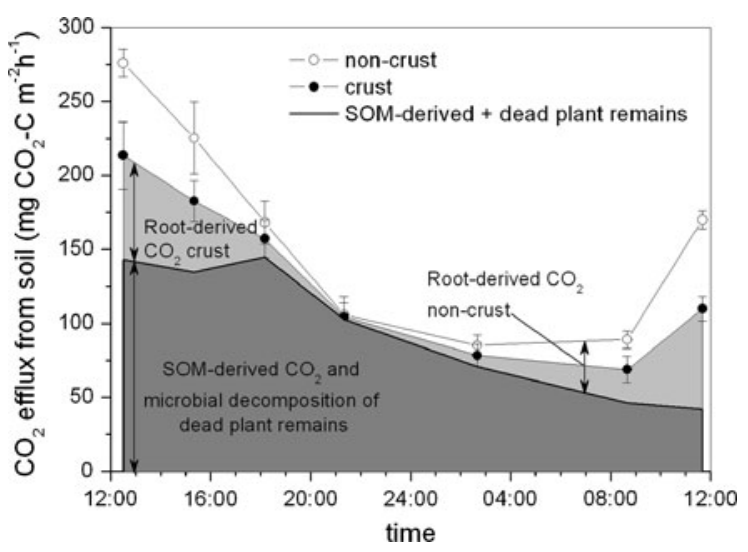

Fig. 2 Typical diurnal dynamics of $\mathrm{CO}_{2}$ efflux from soil $( \pm \mathrm{SE})$ in crust and non-crust vegetation patches (from 14. 08. $200912: 00$ to $15.08 .200912: 00(n=4))$ and its partitioning based on the data of the regression approach. The arrows demonstrate $\mathrm{CO}_{2}$ derived from SOM and microbial decomposition of dead plant remains, and of root-derived $\mathrm{CO}_{2}$ in crust and non-crust vegetation patches

in the absence of living roots, representing the $\mathrm{CO}_{2}$ efflux from the decomposition of dead roots and SOM. Based on the average values during 29 days (Table 1), 


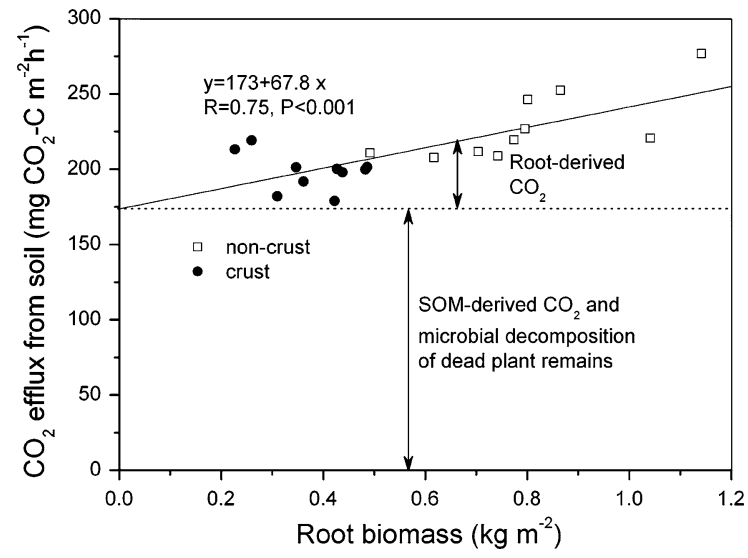

Fig. 3 Contribution of root-derived $\mathrm{CO}_{2}$ and SOM-derived $\mathrm{CO}_{2}$ to the total $\mathrm{CO}_{2}$ efflux from soil calculated based on the linear regression between biomass of living roots and $\mathrm{CO}_{2}$ efflux. Points represent means values $(\mathrm{n}=5)$. Line represents linear correlation. Arrows demonstrate $\mathrm{CO}_{2}$ derived from SOM and microbial decomposition of dead plant remains, and from living roots. Root-derived $\mathrm{CO}_{2}$ is presented for crust versus non-crust plots. Black dots and empty squares indicates soil respiration measured in non-crust and crust patches, respectively

the contribution of root-derived $\mathrm{CO}_{2}$ to total $\mathrm{CO}_{2}$ efflux from soil was estimated to be 18 and $23 \%$ for crust and non-crust patches, respectively. During the nighttime the contribution of root-derived $\mathrm{CO}_{2}$ to total $\mathrm{CO}_{2}$ efflux from soil ranged from 2 to $33 \%$ for crust patches and from 3 to $49 \%$ for non-crust patches.

Fate of root exudates in soil

The short-term (hours to days) and medium-term (days to weeks) processes in soil were examined based on the transformation of three ${ }^{13} \mathrm{C}$ labeled low molecular weight organic substances representing three main groups of root exudates. Short-term processes were described based on mineralization rates, and mediumterm processes according to the residual ${ }^{13} \mathrm{C}$ remaining in soil. After ${ }^{13} \mathrm{C}$ labeled substances were added, a very rapid ${ }^{13} \mathrm{CO}_{2}$ efflux occurred and lasted for 3 days at an initial phase, indicating mineralization of initial substances. This pattern was similar for all treatments and organic substances. A single exponential decay equation with a constant (Eq. 1) fitted well to the measured data $\left(\mathrm{R}^{2}>0.98\right.$ in all treatments). The glucose decomposition rate $\left(0.73 \pm 0.23\right.$ day $^{-1}$ non-crust vs. $0.70 \pm 0.12 \mathrm{day}^{-1}$ crust) was significantly lower than that of glycine $\left(1.42 \pm 0.23 \mathrm{day}^{-1}\right.$ non-crust vs. $1.53 \pm 0.25 \mathrm{day}^{-1}$ crust $)$ for both treatments $(p<0.01)$. However, no significant differences $(p>0.05)$ in decomposition rates were found between crust and non-crust soils (Table 2).

Table $2{ }^{13} \mathrm{C}$ recovery from three LMWOS in various $\mathrm{C}$ pools in Tibetan grassland 29 days after the labeling (\% of total added)

\begin{tabular}{|c|c|c|c|c|c|c|}
\hline \multirow[t]{2}{*}{ Sample } & \multicolumn{2}{|l|}{ Glucose } & \multicolumn{2}{|l|}{ Glycine } & \multicolumn{2}{|l|}{ Acetic acid } \\
\hline & Non-crust & Crust & Non-crust & Crust & Non-crust & Crust \\
\hline Soil total $(0-30 \mathrm{~cm})$ & $30.9 \pm 2.68$ & $38.2 \pm 5.32$ & $54.6 \pm 6.04$ & $65.7 \pm 4.72$ & $29.7 \pm 6.75$ & $39.6 \pm 5.03$ \\
\hline $0-5 \mathrm{~cm}$ & $16.8 \pm 1.15$ & $31.9 \pm 4.41$ & $28.7 \pm 2.18$ & $57.0 \pm 2.89$ & $26.0 \pm 6.24$ & $36.0 \pm 4.94$ \\
\hline $5-15 \mathrm{~cm}$ & $6.25 \pm 0.87$ & $6.21 \pm 0.90$ & $13.5 \pm 3.12$ & $2.49 \pm 0.62$ & - & - \\
\hline $15-30 \mathrm{~cm}$ & $7.89 \pm 0.66$ & $0.06 \pm 0.01$ & $12.4 \pm 0.74$ & $6.20 \pm 1.21$ & $3.65 \pm 0.51$ & $3.64 \pm 0.09$ \\
\hline Total living biomass & $16.3 \pm 1.76$ & $6.70 \pm 0.38$ & $31.1 \pm 0.99$ & $14.6 \pm 0.79$ & $9.63 \pm 0.74$ & $4.60 \pm 0.32$ \\
\hline Above ground (shoots) & $1.80 \pm 0.60$ & $0.24 \pm 0.08$ & $1.72 \pm 0.05$ & $0.23 \pm 0.01$ & $0.52 \pm 0.21$ & $0.07 \pm 0.03$ \\
\hline Living roots & $14.5 \pm 1.16$ & $6.46 \pm 0.30$ & $29.3 \pm 0.94$ & $14.4 \pm 0.78$ & $8.84 \pm 0.53$ & $4.53 \pm 0.29$ \\
\hline $0-5 \mathrm{~cm}$ & $5.61 \pm 0.45$ & $1.51 \pm 0.17$ & $10.8 \pm 0.01$ & $4.39 \pm 0.33$ & $3.37 \pm 0.12$ & $1.31 \pm 0.15$ \\
\hline $5-15 \mathrm{~cm}$ & $4.59 \pm 0.40$ & $2.79 \pm 0.11$ & $10.9 \pm 0.64$ & $5.53 \pm 0.27$ & $2.81 \pm 0.22$ & $1.94 \pm 0.03$ \\
\hline $15-30 \mathrm{~cm}$ & $4.28 \pm 0.31$ & $2.16 \pm 0.02$ & $7.64 \pm 0.29$ & $4.43 \pm 0.18$ & $2.66 \pm 0.19$ & $1.28 \pm 0.11$ \\
\hline Dead roots & $1.33 \pm 0.22$ & $3.11 \pm 0.25$ & $1.96 \pm 0.08$ & $3.49 \pm 0.16$ & $1.66 \pm 0.11$ & $3.05 \pm 0.24$ \\
\hline $0-5 \mathrm{~cm}$ & $0.49 \pm 0.08$ & $1.14 \pm 0.09$ & $0.72 \pm 0.03$ & $1.28 \pm 0.06$ & $0.61 \pm 0.05$ & $1.14 \pm 0.09$ \\
\hline $5-15 \mathrm{~cm}$ & $0.41 \pm 0.07$ & $0.96 \pm 0.08$ & $0.60 \pm 0.03$ & $1.07 \pm 0.05$ & $0.51 \pm 0.04$ & $0.93 \pm 0.07$ \\
\hline $15-30 \mathrm{~cm}$ & $0.43 \pm 0.07$ & $1.01 \pm 0.08$ & $0.64 \pm 0.02$ & $1.14 \pm 0.05$ & $0.54 \pm 0.02$ & $0.98 \pm 0.08$ \\
\hline${ }^{13} \mathrm{CO}_{2}$ efflux from soil & $25.4 \pm 0.51$ & $23.0 \pm 1.08$ & $24.9 \pm 1.79$ & $28.2 \pm 7.50$ & $29.2 \pm 3.26$ & $30.3 \pm 2.18$ \\
\hline Recovered & $73.9 \pm 5.17$ & $71.0 \pm 7.03$ & $113 \pm 8.90$ & $112 \pm 13.2$ & $70.2 \pm 10.9$ & $77.6 \pm 7.53$ \\
\hline
\end{tabular}

Values represent means $\pm \mathrm{SE}(\mathrm{n}=3)$ 
The rapid ${ }^{13} \mathrm{CO}_{2}$ emission was exchanged by slower evolution phase that was well described by the cumulative ${ }^{13} \mathrm{CO}_{2}$ efflux (Fig. 4). This phase was characterized by the decomposition of metabolites of the initial substances as well as the metabolites incorporated in microorganisms and temporarily absorbed to soil particles (and thus protected from fast microbial decomposition). The cumulative $\mathrm{CO}_{2}$ efflux conformed well to a single exponential decay equation with constant $\left(\mathrm{R}^{2}>0.98\right.$ in all treatments; Eq. 2; Fig. 4). Decomposition rates of metabolites $\left(0.06-0.15 \mathrm{day}^{-1}\right)$ were about one order of magnitude slower than that of initial substances $\left(0.70-1.53 \mathrm{day}^{-1}\right)$. Slow decomposition rates for the

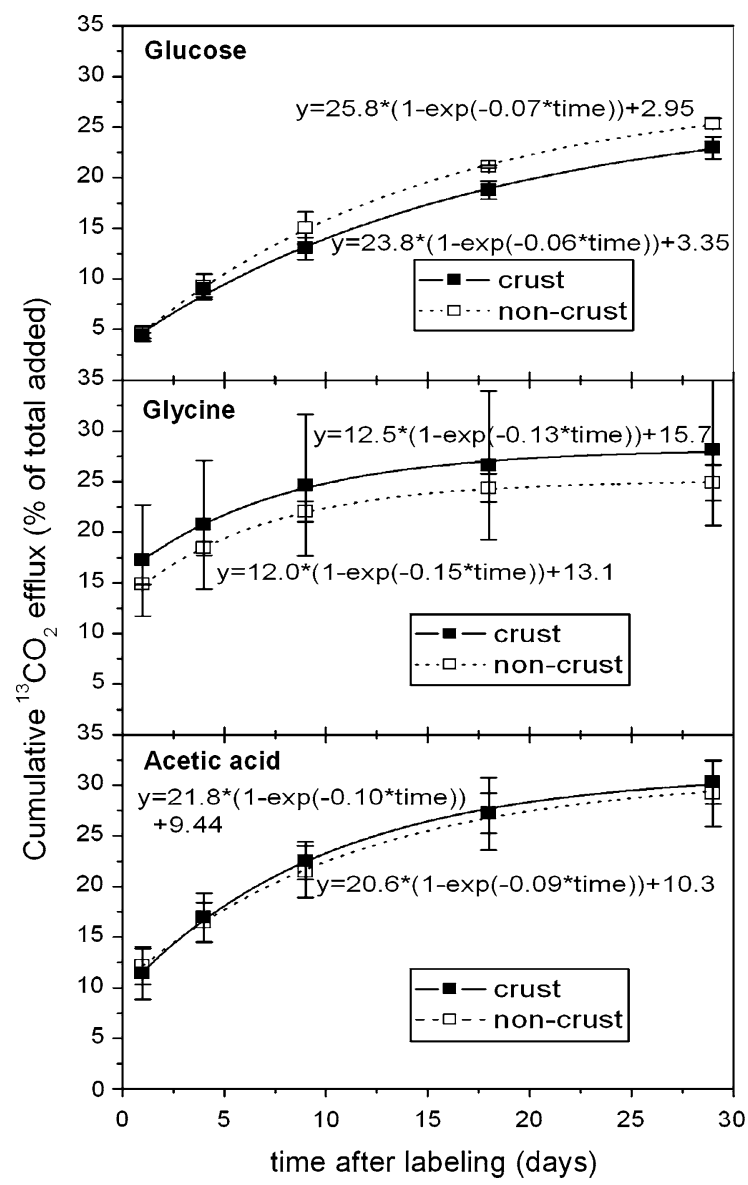

Fig. 4 Measured (filled square, open square) and fitted (lines) cumulative ${ }^{13} \mathrm{CO}_{2}$ efflux $( \pm \mathrm{SE})$ from soil by decomposition of ${ }^{13} \mathrm{C}$-labeled glucose, glycine and acetic acid; 29 day period $(n=3)$. Values represent the amount of ${ }^{13} \mathrm{C}$ recovered as a percentage of total ${ }^{13} \mathrm{C}$ added. Statistical significance for cumulative ${ }^{13} \mathrm{CO}_{2}$ efflux with increasing time for glucose, glycine and acetic acid is at $P<0.01$ level, with $\mathrm{R}^{2}>0.99$ second phase were reflected in long half-lives (Table 3). The decomposition rate of glucose metabolites was significantly lower than that of glycine and of acetic acid in both vegetation patches. However, no significant differences were observed between crust and non-crust $(p>0.05)$.

In contrast to the results obtained based on ${ }^{13} \mathrm{CO}_{2}$ fluxes, the ${ }^{13} \mathrm{C}$ remaining after 29 days in the soil $(0-5 \mathrm{~cm})$ differed significantly in the two vegetation patches (Fig. 5). The minimum amount of the added ${ }^{13} \mathrm{C}$ was found in the soil without crust $(0-5 \mathrm{~cm})$ after glucose addition (17\% of total added) and the maximum after glycine addition in the soil under crust (57\% of total added). With an exception of acetic acid under crust, the ${ }^{13} \mathrm{C}$ of the initial substances and metabolites were described well by a single exponential decay equation with a constant (Eq. $3, \mathrm{R}^{2}>0.77$; Fig. 5). The quantity of remaining ${ }^{13} \mathrm{C}$ was up to 2 times higher under crust $(p<0.01$; Fig. 5), reflecting slower medium-term processes of $\mathrm{C}$ turnover as compared to the non-crust Kobresia patches and/or low plant uptake.

Much less ${ }^{13} \mathrm{C}$ from added exudates was found for all treatments at 5-15 and 15-30 cm depth compared with the upper layer $(0-5 \mathrm{~cm})$ (Table 2). Totally, about $31-38 \%$ of ${ }^{13} \mathrm{C}$-glucose, $55-66 \%$ of ${ }^{13} \mathrm{C}$ glycine and $30-40 \%$ of ${ }^{13} \mathrm{C}$-acetic acid remained in the soil $(0-30 \mathrm{~cm}) 29$ days after labeling, with significantly greater amounts under crust (Table 2). This indicates much slower turnover and higher remains of root exudates under crust.

When evaluating the fate of exudates and ${ }^{13} \mathrm{C}$ budget, the uptake by plants should be considered. Already 1 day after addition, $5.2 \%$ of total ${ }^{13} \mathrm{C}$ added glucose, $10.8 \%$ of glycine and $3.7 \%$ of acetic acid were recovered in the roots (non-crust, depth 0-5 cm). This indicates an initial rapid uptake. However, most ${ }^{13} \mathrm{C}$ remained in the roots and was not transferred to the shoots even after 29 days (Table 2). Two times more ${ }^{13} \mathrm{C}$ was recovered in the living roots under non-crust versus crust, showing that roots play a very important role in the turnover of substances in this ecosystem. Up to $2 \%$ of total added ${ }^{13} \mathrm{C}$ was recovered in the dead roots under non-crust and about twice that amount was recovered in dead roots under the crust (Table 2 ). ${ }^{13} \mathrm{C}$ recovery under both patches clearly shows that the higher ${ }^{13} \mathrm{C}$ remaining in soil under the crust and a lower ${ }^{13} \mathrm{C}$ uptake by living roots. 
Table 3 Half-lives $\left(\mathrm{T}_{1 / 2}\right)$ of ${ }^{13} \mathrm{C}$ labeled substances and metabolites in soil derived from single exponential decay equation fitted to ${ }^{13} \mathrm{CO}_{2}$ efflux

\begin{tabular}{|c|c|c|c|c|c|c|}
\hline & \multicolumn{3}{|c|}{$\mathrm{T}_{1 / 2}$ of initial ${ }^{13} \mathrm{C}$-substances (days) } & \multicolumn{3}{|c|}{$\mathrm{T}_{1 / 2}$ of ${ }^{13} \mathrm{C}$-metabolites and ${ }^{13} \mathrm{C}$ in microbial biomass (days) } \\
\hline & Glucose & Glycine & Acetic acid & Glucose & Glycine & Acetic acid \\
\hline Non-crust & $0.95 \pm 0.31$ & $0.49 \pm 0.08$ & $0.52 \pm 0.11$ & $10.0 \pm 0.53$ & $4.67 \pm 0.18$ & $7.81 \pm 0.75$ \\
\hline Crust & $0.99 \pm 0.17$ & $0.45 \pm 0.07$ & $0.64 \pm 0.12$ & $11.7 \pm 0.31$ & $5.26 \pm 0.68$ & $6.86 \pm 0.60$ \\
\hline
\end{tabular}

Half-life is defined as $\ln (2) / \mathrm{k}$. Values represent means $\pm \mathrm{SE}(\mathrm{n}=3)$

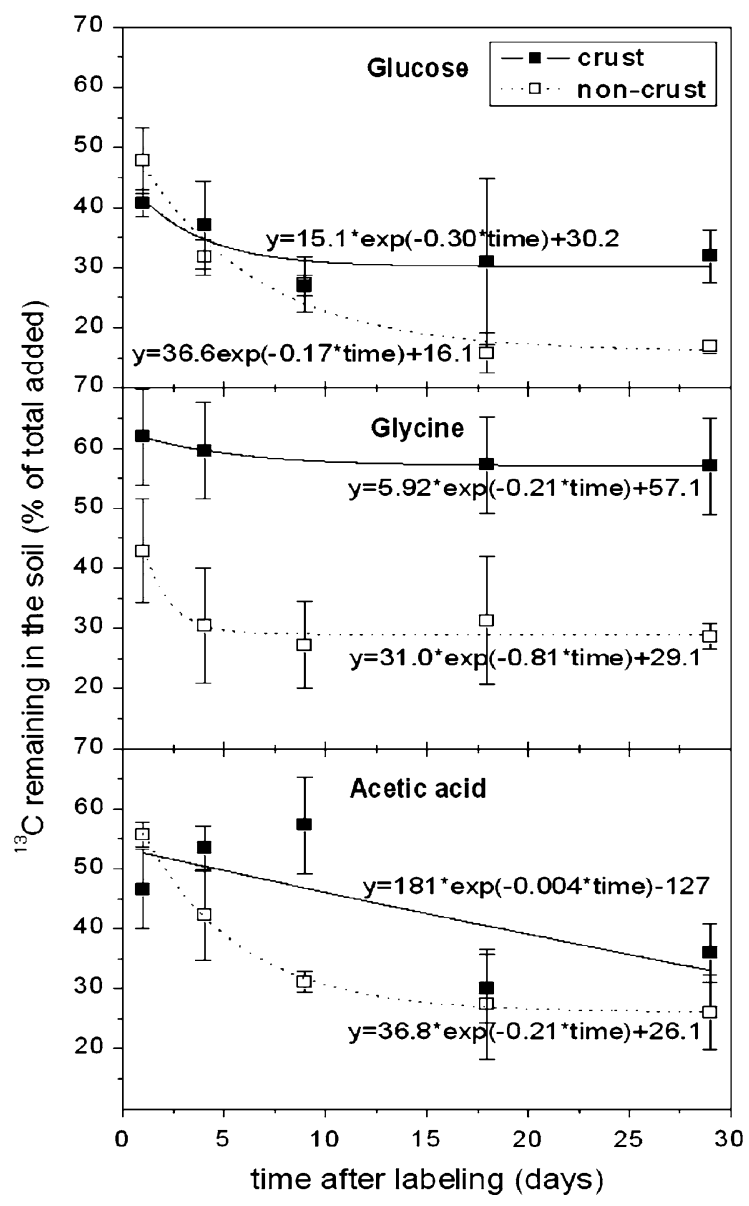

Fig. 5 Measured (filled square, open square) and fitted (lines) ${ }^{13} \mathrm{C}( \pm \mathrm{SE})$ remaining in soil $(0-5 \mathrm{~cm})$ after adding ${ }^{13} \mathrm{C}$-labeled glucose, glycine and acetic acid; 29 day period $(\mathrm{n}=3)$. Values represent the amount of ${ }^{13} \mathrm{C}$ recovered in soil as a percentage of total ${ }^{13} \mathrm{C}$ added. Statistical significance for ${ }^{13} \mathrm{C}$ remaining in the soil for glucose $\left(\mathrm{R}^{2}>0.99\right)$, glycine $\left(\mathrm{R}^{2}>0.99\right)$ and acetic acid $\left(\mathrm{R}^{2}=0.65\right)$ is at $P<0.01$ level

\section{Discussion}

As a result of overgrazing, Kobresia, Stipa and other grasses are partly replaced by blue-green algae and crustose-lichen crusts (Kaiser et al. 2007). This replacement changes the $\mathrm{C}$ cycle differently over long-, medium- and short-term processes.

Changes in carbon stocks

Grasslands play a very important role in the global biogeochemical C cycle (Hall et al. 1995; Sala et al. 1996; Tate et al. 1995). In these ecosystems, C is mostly stored in soils, where turnover-times of the bulk C are relatively long (Hall et al. 1995; Matthews 1997; Tate et al. 1995). Therefore, change in C stocks represents the long-term processes. Natural and anthropogenic changes (e.g., temperature and precipitation, atmospheric $\mathrm{CO}_{2}$ concentration, land-use) in grassland ecosystems have great impact on the $\mathrm{C}$ cycle and may convert the system from a $\mathrm{C}$ sink to a C source or vice versa.

Heavy overgrazing in the Tibetan plateau have formed thick root mats with lichen and blue algae crusts that strongly protect the soil from further degradation because these structures are highly resistant against trampling by yaks and sheep and against erosion (Cao et al. 2010). The above- and belowground C stocks under Kobresia (non-crust) were close to those reported by Wu et al. (2010) for a comparable site at Haibei station with similar altitude and vegetation type. We showed, however, that the two contrasting patches of vegetation (non-crust vs. crust) differed significantly $(p<0.01)$ in both root and shoot biomass. Above- and belowground (shoots and roots) biomass was significantly $(p<0.001)$ smaller under crusts than under non-crust $\left(23.6 \mathrm{~g} \mathrm{C} \mathrm{m}^{-2}\right.$ crusts vs.

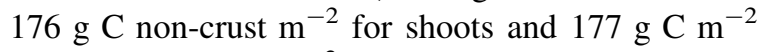
crusts vs. $341 \mathrm{~g} \mathrm{C} \mathrm{m}^{-2}$ non-crust for roots, Table 1). This indicates that the annual $\mathrm{C}$ input by roots and rhizodeposits strongly decreased under crusts. Besides, microbial decomposition of dead plant remains and SOM, did not differ significantly in crust vs. non-crust ( $p>0.05$ ), indicating the same $\mathrm{C}$ output on crust patches. This means that crust formation will lead to 
decreasing $\mathrm{C}$ sequestration or even increasing $\mathrm{C}$ loss over the long-term. This was further confirmed by significant differences $(p<0.05)$ in the $C$ content of the upper soil layer $(0-5 \mathrm{~cm})$ between two different vegetation patches. We therefore conclude that longterm processes have just started to reflect the changes in $\mathrm{C}$ pools due to overgrazing.

It has been reported that intact Kobresia pastures are a neutral net ecosystem $\mathrm{CO}_{2}$ exchange (NEE) on the annual scale (Shi et al. 2006; Zhao et al. 2006; Pei et al. 2009). However, the grazing-induced reduction of above- and belowground biomass, as well as the decline of $\mathrm{C}$ content in the upper soil layer, lead us to expect a decrease of the $\mathrm{C}$ stock under crust in the near future.

$\mathrm{CO}_{2}$ efflux from soil

The $\mathrm{CO}_{2}$ efflux from soil is the major pathway for $\mathrm{C}$ losses from terrestrial ecosystems. The SOM-derived $\mathrm{CO}_{2}$ characterizes the long-term processes and reflects responses to land-use changes (Chen et al. 2009). In contrast, root-derived $\mathrm{CO}_{2}$ contributes to an increased rate of total efflux, but has no influence on the long-term C stock (Kuzyakov 2006). The efflux rates in our study varied between 4.0 and $5.4 \mathrm{~g} \mathrm{C} \mathrm{m}^{-2}$ day $^{-1}$, similar to the observation (3.3 and $4.6 \mathrm{~g} \mathrm{CO}_{2}-\mathrm{C} \mathrm{m}^{-2}$ day $^{-1}$ for heavily and lightly grazed sites, respectively) in an alpine Kobresia humilis meadow from mid-July to August (Cao et al. 2004). The linear regression approach showed low contribution of root-derived $\mathrm{CO}_{2}$ to total $\mathrm{CO}_{2}$ efflux (18\% for crust vs. $23 \%$ for non-crust) in alpine grasslands. Despite some limitations of this approach (Kuzyakov 2006), these values fall within the range (17-40\%) in grassland soils reported by Raich and Tufekcioglu (2000). The contribution of root-derived $\mathrm{CO}_{2}$ are also comparable to that $(26.5 \%)$ estimated by a root removal technique in another alpine Kobresia humilis meadow (Wu et al. 2005), but are less than those (from 25 to $72 \%$ ) observed in a temperate grassland in northern China (Wang et al. 2007).

Diurnal dynamics of $\mathrm{CO}_{2}$ efflux from soil reflect an integrative effect of biotic and abiotic factors on various $\mathrm{C}$ turnover processes over a day scale (i.e., the difference between daytime and nighttime). Higher contribution of living roots to the total $\mathrm{CO}_{2}$ during the daytime is explained by tight connection to photosynthesis (Kuzyakov and Gavrichkova 2010). Besides, the SOM-derived $\mathrm{CO}_{2}$ was approximately three times higher at the start of measurement period than at the end of the measurement period (Fig. 3), indicating that decomposition rates of SOM vary greatly within few days. This is mainly connected with the interactions between soil temperature and moisture affecting microbial activity and consequently SOM decomposition.

This study was not designed to evaluate the contribution of crust to $\mathrm{CO}_{2}$ efflux from soil. We assume however, that this contribution is relatively small, as lichens and algae cover only the upper 5-7 $\mathrm{mm}$ of soil surface and this is negligible as compared to the layer of $6 \mathrm{~cm}$ with living and dead roots (Table 4). Additionally, the $\mathrm{CO}_{2}$ efflux from soil was not significantly different between crust and noncrust patches $\left(5.4 \mathrm{~g} \mathrm{C} \mathrm{m}^{-2} \mathrm{day}^{-1}\right.$ non-crust vs. $5.1 \mathrm{~g} \mathrm{C} \mathrm{m}^{-2} \mathrm{~d}^{-1}$ crust). However, further experiments should be designed to evaluate the contribution of the algae and lichen crusts to $\mathrm{CO}_{2}$ efflux from soil.

Crust patches are especially sensitive to climatic factors such as solar radiation, drought and heavy rain. Particularly solar radiation at high altitudes has a strong effect because it rapidly heats up the vegetation-free and darkish crust surface. This accelerates the SOM and root litter decomposition. At the same time, the surface occupied by lichens increases water run-off and hinders infiltration into the soil. Additionally, higher soil surface temperature and increased wind contact accelerate evaporation and

Table 4 Properties of soil horizons of the Haplic Kastanozem on the Tibetan Plateau near Xinghai

\begin{tabular}{llllllll}
\hline Depth $(\mathrm{cm})$ & Horizon symbol & Soil structure & Bulk density $\left(\mathrm{g} \mathrm{cm}^{-3}\right)$ & $\mathrm{pH}$ & $\mathrm{C}_{\text {org }}^{\mathrm{a}}(\%)$ & Total N $(\%)$ & $\mathrm{C} / \mathrm{N}$ ratio \\
\hline $0-6$ & Afe & Felty & $0.60 \pm 0.01$ & $6.64 \pm 0.15$ & $8.80 \pm 0.20$ & $0.68 \pm 0.01$ & $12.9 \pm 0.60$ \\
$6-25$ & Ahk & Granular & $0.81 \pm 0.01$ & $6.96 \pm 0.19$ & $4.38 \pm 0.15$ & $0.46 \pm 0.01$ & $9.52 \pm 0.54$ \\
$25-90$ & Bkc & Angular & $0.84 \pm 0.01$ & $7.62 \pm 0.04$ & $2.28 \pm 0.19$ & $0.25 \pm 0.02$ & $9.12 \pm 1.62$ \\
\hline
\end{tabular}

${ }^{a}$ dead and living roots were removed prior to $\mathrm{C}_{\text {org }}$ and total $\mathrm{N}$ analyses

b Kaiser et al. (2007) 
reduce soil moisture. Previous study showed that higher temperature enhances $\mathrm{CO}_{2}$ efflux in Kobresia grasslands (Saito et al. 2009), but moisture is probably the major limiting factor for $\mathrm{CO}_{2}$ efflux from soil (Yang et al. 2008) under the crust patches. Low moisture may also be responsible for more ${ }^{13} \mathrm{C}$ remaining in the soil under crust after the exudate addition. Future work should therefore be devoted to evaluating the importance of individual climatic factors and their interactions as well as the response of these two contrasting vegetation patches.

Fate of root exudates in soil

The fate of root exudates and their metabolites in soil and plants reflects short- and medium-term processes. A large portion of ${ }^{13} \mathrm{C}$ derived from glucose (about $31-38 \%$ of total ${ }^{13} \mathrm{C}$ added), glycine $(55-66 \%)$ and acetic acid (30-40\%) was recovered in the $30 \mathrm{~cm}$ soil 29 days after labeling, with larger values for crusted soil. In contrast to the release of rhizodeposits after ${ }^{13} \mathrm{C}$ plant labeling (Wu et al. 2010), directly adding ${ }^{13} \mathrm{C}$ labeled substances to the soil resulted in a much higher percentage of remaining ${ }^{13} \mathrm{C}$. Based on decomposition rates, the calculated half-lives for exudates in soil were $0.86-4.05$ days. These halflives are similar to that of glucose (4 days) in a Brown Chernozemic soil (Shields et al. 1973) and are within the range of values for easily available organic substances as reviewed by Jones et al. (2005a, b). However, the half-lives were much shorter than those of organic substances incorporated in microorganisms, e.g., 0.25-2.5 years for various organics in forest soils (van Hees et al. 2005; Blagodatskaya et al. 2011), 56.8 days (glucose) for soil under ryegrass (Kouno et al. 2002) and 60 days (glucose) in soil from permanent grassland (Wu et al. 1993).

Numerous studies under field and controlled conditions have suggested that temperature strongly enhances decomposition of SOM and LMWOS (Kirschbaum 1995; Luo and Zhou 2006). To regret, we have not measured the soil temperature under crusted and not-crusted patches. We assume however, that because the dark crust surfaces were directly prone to solar radiation, their temperature was higher than under the non-crust patches. A clipping experiment in an alpine grassland showed that soil temperatures under non-vegetated areas may be up to $5^{\circ} \mathrm{C}$ higher compared to areas covered by vegetation, resulting in an increase of respiratory activity for 20-50\% (Bahn et al. 2006). This indicates that an increase in soil temperature under crusted soil may increase mineralization of added low-molecular weight organic substances (LMWOS) and lead to more ${ }^{13} \mathrm{CO}_{2}$ emission from the crust soil. However, only a small difference in the ${ }^{13} \mathrm{CO}_{2}$ release from added LMWOS between crust and non-crusted soil were observed (Fig. 4). Three reasons may be responsible for the small differences despite the expected temperature differences. Firstly, the very dense Kobresia root mats have extremely wellinsulating properties. Therefore, we assume that the temperature may be different between crusts und noncrusts on the surface, but is very similar in few mm of soil depths. Secondly, the intensive solar radiation, leading to high soil surface temperatures, is common at this site only for some days and only between 10 am and 2 pm. Nearly all afternoons are cloudy with frequent short thunderstorms. As the ${ }^{13} \mathrm{CO}_{2}$ release was measured continuously, the temperature increase for 3-4 h during some days has only a small contribution to the total decomposition of LMWOS. Thirdly, the small difference in ${ }^{13} \mathrm{CO}_{2}$ between the crust and non-crust might result from the fact that other factors such as low water content counteract the effect of soil temperature on mineralization of added LMWOS.

Significantly more ${ }^{13} \mathrm{C}(p<0.01)$ remained in the soil $(0-5 \mathrm{~cm})$ under crusts (Fig. 4). There are two possible explanations: (i) limitation by abiotic factors, mainly moisture (see above): the water content was considerably lower in the crust patches; (ii) lower microbial activity under crust with less living roots (Blagodatskaya et al. 2010), leading to slower decomposition of organic substances in the rhizosphere (Kuzyakov 2002; Cheng 2009). However, this needs further experimental confirmation.

An explanation to the lower ${ }^{13} \mathrm{C}$ amount remaining in non-crust soil is the higher uptake of exudates and their metabolites by roots. Roots can take up dissolved low molecular weight organics passively or via a range of active proton cotransport systems mainly used for amino acid uptake (Jones 1999; Bardgett et al. 2003; Xu et al. 2004; Jones et al. 2005a). The relevance of this uptake, however, is low for most ecosystems, and the experimental approaches based on bulk ${ }^{13} \mathrm{C}$ and ${ }^{15} \mathrm{~N}$ were questioned recently (Biernath et al. 2008; Sauheitl et al. 2009; Rasmussen et al. 2010). In Kobresia 
grassland, 16, 31 and $10 \%$ of the ${ }^{13} \mathrm{C}$ from glucose, glycine and acetic acid, respectively, were recovered in the roots $(0-30 \mathrm{~cm})$ and shoots 29 days after labeling. The higher uptake of glycine compared to glucose and acetic acid (Table 2) shows the importance of nitrogen (N) to plants in this N-limited ecosystem (Jones and Darrah 1994). However, only less than $6 \%$ of this amount was transferred in the shoots (except glucose without crust), with the minimal values under crusts. There are two possible explanations to this very low transport of ${ }^{13} \mathrm{C}$ substances and their metabolites from roots to shoots. First, the ${ }^{13} \mathrm{C}$ recovered in the roots was not really taken up by the roots, but was moved with water to the roots and remained at the pericycle without to enter in the symplast. Secondly, some ${ }^{13} \mathrm{C}$ allocated from roots to the shoots could be lost via shoot respiration. This has been observed by organic $\mathrm{N}$ uptake using ${ }^{13} \mathrm{C}$-labeled amino acids (Näsholm and Persson 2001). The higher uptake of added substances compared to other studies (Boddy et al. 2007; Henry and Jefferies 2003) mainly reflects the first reason (passive movement and remaining at pericycle) by very dense roots of Kobresia mats. This is because the total uptake of substances strongly depends on root density (Xu et al. 2011) that was extremely high under Kobresia as compared to most other ecosystems. While other studies (Bardgett et al. 2003; Jones et al. 2005a) stated that roots are poor competitors for dissolved organics compared with microorganisms, we cannot support these findings. A significantly higher portion of organics entering the soil remains in soil under crust could be ascribed to lower uptake by living roots and longer period of this study than other studies. E.g., Jones et al. (2005a, b) showed no effects of agricultural management on amino acid mineralization and suggested that very fast processes do not reflect changes on medium- and long-term scales. In this study we observed that exudate decomposition did not differ significantly between crust and non-crust, confirming the conclusion of Jones et al. (2005a, b). Because the rate of ${ }^{13} \mathrm{CO}_{2}$ evolution was rapid, with half-lives ranging from 0.45 to 0.99 days (Table 3 ), we suggest that the initial mineralization of the added exudates is probably too fast to evaluate crust/non-crust differences under field conditions.

Glucose, glycine and acetic acid mineralization in soil is extremely rapid compared with more complex substrates, e.g., cellulose and proteins (Tate et al. 2000; Schneckenberger et al. 2008). Nevertheless, half-lives are longer than those reported for low molecular weight solutes released from plant cells into the rhizosphere, e.g., glucose (Hill et al. 2008; Schneckenberger et al. 2008; Kuzyakov and Jones 2006), amino acids (Boddy et al. 2007) or carboxylic acids (Jones 1998; Fischer et al. 2010a, b). This indicates that microbial activity in both grassland soils in the Tibetan Plateau was lower than in soils of other ecosystems.

We hypothesized lower decomposition rates under crust because of lower microbial activity due to the two-times-lower living root biomass. However, the mineralization rates were similar in both vegetation patches. Thus, our study indicates that crust patches had no effect on fast processes of exudate turnover or these effects were not captured because of very fast mineralization and root uptake. However, we have to mention that only a very narrow range of fast decomposition processes were traced here based on ${ }^{13} \mathrm{C}$ labeled glucose, glycine and acetic acid. Therefore, the fate of substances with other biochemical properties as well as with slower decomposition rates should be compared in soils with and without crust.

\section{Conclusions}

The lichen-algae crusts on the Kobresia root mat resulting from heavy overgrazing mainly change the $\mathrm{C}$ stock in aboveground and living root biomass. Contrary to our hypothesis, we found no effects of crust on fast processes as reflected by mineralization of root exudates. Nonetheless, a significantly larger portion of organics entering the soil remains under crusts for a long period. Despite a smaller input, a larger portion of exudates is incorporated into SOM and microorganisms, while less is taken up by living roots and decomposed to $\mathrm{CO}_{2}$. The strongly decreased $\mathrm{C}$ input by living roots under crusts is therefore partly compensated by the slower mediumterm processes and the higher portion of organics remaining in soil. It is partly confirmed by the decreased $\mathrm{C}$ content in the upper soil layer that the slower decomposition cannot compensate decreased $\mathrm{C}$ input in this fragile ecosystem, but longer studies are necessary to investigate the balance between the decreased $\mathrm{C}$ input and slower decomposition. Therefore, changing vegetation patterns and the increase in crust area need to be monitored to prevent farreaching negative effects on the Kobresia pasture 
ecosystems and to prevent a shift from a neutral $\mathrm{C}$ balance to a $\mathrm{C}$ source.

Acknowledgments We greatly acknowledge the support of this study by the German Research Foundation (DFG) within the Priority Programme 1372 "Tibetan Plateau: Formation Climate - Ecosystems (TiP)" and by Project Based Exchange Programme (PPP) of the German Academic Exchange Service (DAAD) as well as the Chinese Academy of Sciences Visiting Professorship awarded to Yakov Kuzyakov.

Open Access This article is distributed under the terms of the Creative Commons Attribution Noncommercial License which permits any noncommercial use, distribution, and reproduction in any medium, provided the original author(s) and source are credited.

\section{References}

Bahn M, Knapp M, Garajova Z, Fahringer NP, Cernusca A (2006) Root respiration in temperate mountain grasslands differing in land use. Global Change Biol 12:995-1006

Bardgett RD, Streeter TC, Bol R (2003) Soil microbes compete effectively with plants for organic-nitrogen inputs to temperate grasslands. Ecology 84:1277-1287

Biernath C, Fischer H, Kuzyakov Y (2008) Root uptake of $\mathrm{N}$-containing and $\mathrm{N}$-free low molecular weight organic substances by maize - a 14C/15 N tracer study. Soil Biol Biochem 40:2237-2245

Blagodatskaya E, Blagodatsk S, Dorodnikov M, Kuzyakov Y (2010) Elevated atmospheric $\mathrm{CO}_{2}$ increases microbial growth rates in soil: results of three $\mathrm{CO}_{2}$ enrichment experiments. Global Change Biol 16:836-848

Blagodatskaya E, Yuyukina T, Blagodatsky S, Kuzyakov Y (2011) Turnover of soil organic matter and microbial biomass under $\mathrm{C} 3-\mathrm{C} 4$ vegetation change: consideration of $13 \mathrm{C}$ fractionation and preferential substrate utilization. Soil Biol Biochem 43:159-166

Boddy E, Hill PW, Farrar J, Jones DL (2007) Fast turnover of low molecular weight components of the dissolved organic carbon pool of temperate grassland field soils. Soil Biol Biochem 39:827-835

Cao GM, Long RJ (2009) System stability and its self-maintaining mechanism by grazing in alpine Kobresia meadow. Chin J Agrometeorol 30:553-559

Cao GM, Tang YH, Mo WH, Wang YA, Li YN, Zhao XQ (2004) Grazing intensity alters soil respiration in an alpine meadow on the Tibetan plateau. Soil Biol Biochem 36:237-243

Cao G, Lin L, Zhang F, Li Y, Han D, Long R (2010) A review of maintenance, loss and recovery of stability of alpine Kobresia humilis meadow on Tibetan Plateau. Pracultural Sci 27:34-38

Chen H, Hou R, Gong Y, Li H, Kuzyakov Y (2009) Effects of 11 years of conservation tillage on soil organic matter fractions in wheat monoculture in Loess Plateau of China. Soil Till Res 106:85-94
Cheng W (2009) Rhizosphere priming effect: its functional relationships with microbial turnover, evapotranspiration, and C-N budgets. Soil Biol Biochem 41:1795-1801

Cui XF, Graf HF (2009) Recent land cover changes on the Tibetan Plateau: a review. Clim Change 94:47-61

Fischer H, Ingwersen J, Kuzyakov Y (2010a) Microbial uptake of low molecular weight organic substances outcompetes sorption by the whole range of concentrations in soil. Eur J Soil Sci 61:504-513

Fischer H, Eckhardt KU, Meyer A, Neumann G, Leinweber P, Fischer K, Kuzyakov Y (2010b) Rhizodeposition of maize-short term carbon budget and composition. J Plant Nutr Soil Sci 173:67-79

Gad G (2005) Towards market oriented economy. Reforms in the mobile livestock herds of the Tibetan highlands in the P.R. of China. Occasional paper 29. Geographie, Freie Universität Berlin

Gocke M, Pustovoytov K, Kuzyakov Y (2011) Carbonate recrystallization in root-free soil and rhizosphere of Triticum aestivum and Lolium perenne estimated by ${ }^{14} \mathrm{C}$ labeling. Biogeochemistry 103:209-222

Hafner S, Unteregelsbacher S, Seeber E, Xu X, Li X, Guggenberger G, Miehe G, Kuzyakov Y (2011) Effect of grazing on carbon stocks and assimilate partitioning in Tibetan montane pasture revealed by ${ }^{13} \mathrm{CO}_{2}$ pulse labeling. Global Change Biol (in press)

Hall DO, Ojima DS, Parton WJ, Scurlock JMO (1995) Response of temperate and tropical grasslands to $\mathrm{CO}_{2}$ and climate change. J Biogeogr 22:537-547

Henry HAL, Jefferies RL (2003) Plant amino acid uptake, soluble $\mathrm{N}$ turnover and microbial $\mathrm{N}$ capture in soils of a grazed Arctic salt marsh. J Ecol 91:627-636

Hill PW, Farrar JF, Jones DL (2008) Decoupling of microbial glucose uptake and mineralization in soil. Soil Biol Biochem 40:616-624

Jones DL (1998) Organic acids in the rhizosphere-a critical review. Plant Soil 205:25-44

Jones DL (1999) Amino acid biodegradation and its potential effects on organic nitrogen capture by plants. Soil Biol Biochem 31:613-622

Jones DL, Darrah PR (1994) Amino-acid influx at the soil-root interface of Zea mays L. and its implications in the rhizosphere. Plant Soil 163:1-12

Jones DL, Healey JR, Willett VB, Farrar JF, Hodge A (2005a) Dissolved organic nitrogen uptake by plants-an important N uptake pathway? Soil Biol Biochem 37:413-423

Jones DL, Kemmitt SJ, Wright D, Cuttle SP, Bol R, Edwards AC (2005b) Rapid intrinsic rates of amino acid biodegradation in soils are unaffected by agricultural management strategy. Soil Biol Biochem 37:1267-1275

Kaiser K, Schoch WH, Miehe G (2007) Holocene paleosols and colluvial sediments in Northeast Tibet (Qinghai Province, China): Properties, dating and paleoenvironmental implications. Catena 69:91-102

Kirschbaum MUF (1995) The temperature dependence of soil organic matter decomposition, and the effect of global warming on soil organic $\mathrm{C}$ storage. Soil Biol Biochem 27:753-760

Kraffczyk I, Trolldenier G, Beringer H (1984) Soluble root exudates of maize: influence of potassium supply and rhizosphere microorganisms. Soil Biol Biochem 16:315-322 
Kucera CL, Kirkham DR (1971) Soil respiration studies in tallgrass prairie in Missouri. Ecology 52:912-915

Kuzyakov Y (2002) Review: factors affecting rhizosphere priming effects. J Plant Nutr Soil Sci 165:382-396

Kuzyakov Y (2006) Sources of $\mathrm{CO}_{2}$ efflux from soil and review of partitioning methods. Soil Biol Biochem 38:425-448

Kuzyakov Y, Gavrichkova O (2010) Time lag between photosynthesis and carbon dioxide efflux from soil: a review. Global Change Biol 16:3386-3406

Kuzyakov Y, Jones DL (2006) Glucose uptake by maize roots and its transformation in the rhizosphere. Soil Biol Biochem 38:851-860

Kuzyakov Y, Schevtzova E, Pustovoytov K (2006) Carbonate re-crystallization in soil revealed by ${ }^{14} \mathrm{C}$ labeling: experiment, model and significance for paleo-environmental reconstructions. Geoderma 131:45-58

Lu HY, Wu NQ, Gu ZY, Guo ZT, Wang L, Wu HB, Wang G, Zhou LP, Han JM, Liu TS (2004) Distribution of carbon isotope composition of modern soils on the QinghaiTibetan Plateau. Biogeochemistry 70:273-297

Luo Y, Zhou X (2006) Soil respiration and the environment. Academic/Elsevier, San Diego, p 328

Matthews E (1997) Global litter production, pools and turnover times: estimates from measurement data and regression models. J Geophys Res 102(D15):18771-18800

Miehe G, Kaiser K, Co S, Zhao XQ, Liu JQ (2008a) Geoecological transect studies in northeast Tibet (Qinghai, China) reveal human-made mid-holocene environmental changes in the upper Yellow River catchment changing forest to grassland. Erdkunde 62:187-199

Miehe G, Miehe S, Kaiser K, Liu JQ, Zhao XQ (2008b) Status and dynamics of Kobresia pygmaea ecosystem on the Tibetan plateau. Ambio 37:272-279

Miehe G, Miehe S, Bach K, Nölling J, Hanspach J, Reudenbach C, Kaiser K, Wesche K, Mosbrugger V, Yang Y, Ma Y (2011) Plant communities of central Tibetan pastures in the Alpine Steppe/Kobresia pygmaea ecotone. J Arid Env 75:711-723

Näsholm T, Persson J (2001) Plant acquisition of organic nitrogen in boreal forests. Physiol Plantarum 111:419-426

Ni J (2002) Carbon storage in grasslands of China. J Arid Environ 50:205-218

Ning W, Richard C (1999) The privatization process of rangeland and its impacts on pastoral dynamics in the Hindu-Kush Himalaya: the case of western Sichuan, China, pp 1-17

Pei ZY, Ouyang H, Zhou CP, Xu XL (2009) Carbon balance in an alpine steppe in the Qinghai-Tibet plateau. J Integr Plant Biol 51:521-526

Raich JW, Tufekcioglu A (2000) Vegetation and soil respiration: correlations and controls. Biogeochemistry 48:71-90

Rasmussen J, Sauheitl L, Eriksen J, Kuzyakov Y (2010) Plant organic $\mathrm{N}$ uptake is biased by inorganic C: results of triple labeling study. Soil Biol Biochem 42:524-527

Saito M, Kato T, Tang YH (2009) Temperature controls ecosystem $\mathrm{CO}_{2}$ exchange of an alpine meadow on the northeastern Tibetan plateau. Global Change Biol 15:221-228

Sala OE, Lauenroth WK, Burke IC (1996) Carbon budgets of temperate grasslands and the effects of global change. In: Breymeyer A, Hall DO, Melillo JM, Agren GI (eds)
Global change: effects on coniferous forests and grasslands. Wiley, Chichester, New York, pp 101-120

Sauheitl L, Glaser B, Weigelt A (2009) Advantages of compound-specific stable isotope measurements over bulk measurements in studies on plant uptake of intact amino acids. Rapid Com Mass Spectr 23:3333-3342

Schneckenberger K, Demin D, Stahr K, Kuzyakov Y (2008) Microbial utilization and mineralization of $\left[{ }^{14} \mathrm{C}\right]$ glucose added in six orders of concentration to soil. Soil Biol Biochem 40:1981-1988

Shi PL, Sun XM, Xu LL, Zhang XZ, He YT, Zhang DQ, Yu GR (2006) Net ecosystem $\mathrm{CO}_{2}$ exchange and controlling factors in a steppe-Kobresia meadow on the Tibetan plateau. Sci Chin Ser D Earth Sci 49:207-218

Shields JA, Paula EA, Lowea WE, Parkinson D (1973) Turnover of microbial tissue in soil under field conditions. Soil Biol Biochem 5:753-764

Tate KR, Parsholtam A, Ross DJ (1995) Soil carbon storage and turnover in temperate forests and grasslands: a New Zealand perspective. J Biogeogr 22:695-700

Tate KR, Scott NA, Ross DJ, Parshotam A, Claydon JJ (2000) Plant effects on soil carbon storage and turnover in a montane beech (Nothofagus) forest and adjacent tussock grassland in New Zealand. Aust J Soil Res 38:685-698

van Hees PAW, Jones DL, Finlay R, Godbold DL, Lundström US (2005) The carbon we do not see-the impact of low molecular weight compounds on carbon dynamics and respiration in forest soils: a review. Soil Biol Biochem 37:1-13

Wang GX, Cheng GD (2000) Eco-environmental changes and causative analysis in the source regions of the Yangtze and Yellow Rivers, China. Environmentalist 20:221-231

Wang GX, Qian J, Cheng GD, Lai YM (2002) Soil organic carbon pool of grassland soils on the Qinghai-Tibetan plateau and its global implication. Sci Total Env 291:207-217

Wang W, Guo J, Oikawa T (2007) Contribution of root to soil respiration and carbon balance in disturbed and undisturbed grassland communities, northeast China. Bioscience 32:375-384

Wu J, Brookes PC, Jenkinson DS (1993) Formation and destruction of microbial biomass during the decomposition of glucose and ryegrass in soil. Soil Biol Biochem 25:1435-1441

Wu Q, Cao GM, Hu QW, Dong L, Li YM (2005) A primary study on $\mathrm{CO}_{2}$ emission from soil-plant systems of Kobresia humilis meadow. Resour Sci 27:96-102 (In Chinese)

Wu YB, Tan HC, Deng YC, Wu J, Xu XL, Wang YF, Tang YH, Higashi T, Cui XY (2010) Partitioning pattern of carbon flux in a Kobresia grassland on the QinghaiTibetan plateau revealed by field ${ }^{13} \mathrm{C}$ pulse-labeling. Global Change Biol 16:2322-2333

Xu XL, Ouyang H, Cao GM, Pei ZY, Zhou CP (2004) Uptake of organic nitrogen by eight dominant plant species in Kobresia meadows. Nutr Cycl Agroecosys 69:5-10

Xu X, Ouyang H, Cao G, Richter A, Wanek W, Cao G, Kuzyakov Y (2011) Spatio-temporal patterns of plantmicrobe competition for inorganic nitrogen in an alpine meadow. J Ecol 99:563-571 
Yang Y, Fang J, Tan Y, Ji C, Zheng C, He J, Zhu B (2008) Storage, patterns and controls of soil organic carbon in the Tibetan grasslands. Global Change Biol 14:1592-1599

Zhang YQ, Tang YH, Jiang J, Yang YH (2007) Characterizing the dynamics of soil organic carbon in grasslands on the Qinghai-Tibetan plateau. Sci Chin Ser D Earth Sci 50:113-120

Zhao XQ, Zhou XM (1999) Ecological basis of alpine meadow ecosystem management in Tibet: Haibei alpine meadow ecosystem research station. Ambio 28:642-647
Zhao L, Li YN, Zhao XQ, Xu SX, Tang YH, Yu GR, Gu S, Du MY, Wang QX (2005) Comparative study of the net exchange of $\mathrm{CO}_{2}$ in 3 types of vegetation ecosystems on the Qinghai-Tibetan plateau. Chin Sci Bull 50:1767-1774

Zhao L, Li YN, Xu SX, Zhou HK, Gu S, Yu GR, Zhao XQ (2006) Diurnal, seasonal and annual variation in net ecosystem $\mathrm{CO}_{2}$ exchange of an alpine shrubland on Qinghai-Tibetan plateau. Global Change Biol 12:1940-1953 